\title{
Gambaran Faktor Risiko Kejadian Penyakit Jantung Koroner di Poliklinik Jantung RSI Siti Rahmah Padang Tahun 2017-2018
}

\author{
Sari, Yushera Atika ${ }^{1}$, Widiastuti, $\mathrm{W}^{2}$, Fitriyasti, $\mathrm{B}^{3}$
}

\author{
${ }^{1}$ Mahasiswa Fakultas Kedokteran Universitas Baiturrahmah Padang, Indonesia \\ email: yusheraatikas@gmail.com \\ ${ }^{2}$ Bagian Penyakit Dalam, Fakultas Kedokteran Universitas Baiturrahmah Padang, Indonesia \\ ${ }^{3}$ Bagian Biokimia, Fakultas Kedokteran Universitas Baiturrahmah Padang, Indonesia
}

\begin{abstract}
Abstrak
Pendahuluan: Penyakit Jantung Koroner ini terjadi secara tidak langsung, biasanya seseorang akan mengalami proses penyempitan pembuluh koroner dalam kurun waktu yang cukup lama. Hasil primary survey yang telah peneliti lakukan di RSI Siti Rahmah Padang, tercatat dari tahun 2017-2018 jumlah kejadian PJK sebanyak 115 kasus. Tujuan: untuk mendapatkan informasi mengenai gambaran faktor risiko kejadian penyakit jantung koroner di poliklinik jantung RSI Siti Rahmah Padang tahun 2017-2018. Metode: Penelitian ini merupakan penelitian deskriptif, mencakup bidang ilmu penyakit dalam dan ilmu penyakit jantung, penelitian ini di lakukan di rumah sakit Islam Siti Rahmah Padang pada bulan Mei sampai November 2019. Penelitian ini menggunakan metode deskriptif dengan pendekatan cross sectional menggunakan data sekunder dari rekam medik. Populasi terjangkau penelitian ini adalah pasien PJK yang berobat di RSI Siti Rahmah Padang tahun 2017-2018 dengan 51 sampel dengan menggunakan teknik Total Sampling. Analisa univariat disajikan dalam bentuk tabel distribusi frekuensi. Hasil: Berdasarkan hasil penelitian Usia terbanyak berada pada usia 50-59 tahun yaitu 21 orang (41,2\%), jenis kelamin terbanyak adalah perempuan yaitu 26 orang (51\%), hipertensi yaitu 27 orang (52,9\%), DM yaitu 26 orang $(51 \%)$, obesitas yaitu 16 orang $(31,4 \%)$ dan hiperlipidemia yaitu 13 orang $(25,5 \%)$. Kesimpulan: Usia terbanyak 50-59 tahun, jenis kelamin terbanyak perempuan, paling banyak mengalami hipertensi, kurang dari separuh mengalami obesitas, paling banyak DM dan kurang dari separuh mengalami hiperlipidemia.
\end{abstract}

Kata Kunci : PJK, Usia, jenis kelamin, hipertensi, obesitas, DM dan hiperlipidemia

\begin{abstract}
Introduction: $C A D$ occurs indirectly, usually a person will experience a process of narrowing of the coronary arteries in quite a long period of time. Primary survey results that researchers have done at Siti Rahmah Padang Hospital, recorded from 2017-2018 the number of CAD events as many as 115 cases. Aims : To obtain information about an overview of risk factors for the occurrence of coronary artery disease in the heart policlinic of Siti Rahmah Hospital Padang in 2017-2018. Method: This research covers the field of internal medicine and cardiology, this study was conducted at the Islamic hospital Siti Rahmah Padang in May to November 2019. This research used a descriptive method with a cross sectional approach using secondary data from medical records. The affordable population of this study is CAD patients who seek treatment at Siti Rahmah Hospital in Padang in 2017-2018 with 51 samples using Total Sampling technique. Univariate analysis is presented in the form of a frequency distribution table. Results: Based on the results of the study the most age was at the age of 50-59 years, 21 people (41.2\%), the most sex was female, 26 people (51\%), hypertension, 27 people $(52,9 \%)$, experienced DM 26 people $(51 \%)$ were obese, 16 people $(31,4 \%)$ and hyperlipidemia, 13 people $(25,5 \%)$. Conclusion : Most age 50-59 years, most sexes of women, most have hypertension, less than half are obese, most have DM and less than half have hyperlipidemia.
\end{abstract}

Keywords : CAD, age, sex, hypertension, obesity, DM and hyperlipidemia

Email : heme@unbrah.ac.id 


\section{Pendahuluan}

Penyakit Jantung Koroner (PJK) terjadi akibat penyempitan atau penyumbatan di dinding nadi koroner karena adanya endapan lemak dan kolesterol sehingga mengakibatkan suplai darah ke jantung menjadi terganggu. Data Riskesdas 2013 yang termasuk dalam klasifikasi PJK adalah Angina Pektoris dan Infark Miokard. Angina Pektoris disebabkan oleh kurangnya pasokan darah karena penyempitan arteri koroner yang mengakibatkan nyeri dada yang muncul pada saat istirahat ataupun pada saat beraktifitas, bila darah tidak mengalir sama sekali karena arteri koroner tersumbat, penderita dapat mengalami serangan jantung yang disebut Infark Miokard rentang waktu yang lebih lama daripada Angina dan tidak akan membaik dengan istirahat ataupun obat pereda nyeri sampai terjadi pingsan, syok, bahkan meninggal seketika. ${ }^{1}$

Hasil data World Health Organization (WHO) tahun 2014 menunjukkan bahwa PJK menempati angka urutan pertama dari sepuluh penyakit yang mematikan, 9,4 juta kematian setiap tahunnya yang disebabkan kardiovaskular dan $45 \%$ disebabkan oleh PJK. Survei Sample Registration System (SRS) pada tahun 2014 di Indonesia menunjukkan PJK menjadi penyebab kematian tertinggi pada semua umur setelah stroke, yakni sebesar $12,9 \% .^{2}$

Data dari Riskesdas (2018), prevalensi penyakit jantung di Indonesia berdasarkan diagnosis dokter sebesar 1,5\%. Berdasarkan prevalensi tersebut, angka tertinggi terdapat di Provinsi Kalimantan Utara $(2,2 \%)$ dan terendah di Provinsi Nusa Tenggara Timur $(0,7 \%){ }^{3}$

Menurut kelompok umur, PJK paling banyak terjadi pada kelompok >75 tahun $(4,7 \%)$ diikuti kelompok umur 65-74 tahun $(4,6 \%)$, kelompok umur 55-64 tahun (3,9\%), kelompok umur 45-54 tahun $(2,4 \%)$ dan kelompok umur 35-44 tahun $(1,3 \%){ }^{4}$

Data dari Dinas Kesehatan Sumatera Barat, kejadian prevalensi hipertensi di Sumatera Barat pada tahun 2013 sebesar 7,6\%, diabetes mellitus $1,8 \%$, dislipidemia $2,88 \%$, obesitas $19,7 \%$. Kejadian penyakit tersebut cenderung meningkat setiap tahunnya. Hal itulah yang menjadi faktor terus meningkatnya kejadian PJK di Sumatera Barat dan menempati urutan ke-3 besar dari seluruh Indonesia dengan prevalensi kejadian penyakit jantung koroner yaitu sebesar $0,6 \%$ atau sebanyak 20.567 jiwa dan jumlah penderita PJK terbanyak terdapat di provinsi Jawa Barat yaitu sebanyak 160.812 orang, serta penderita PJK terendah di provinsi Maluku Utara sebanyak 1.436 orang. Sumatera Barat diperkirakan 4.400 jiwa meningggal setiap tahunnya akibat PJK. ${ }^{5}$

Tanda dan gejala yang ditimbulkan oleh PJK meliputi rasa berat, tertekan, nyeri, angina pectoris sebagai tanda otot jantung kekurangan oksigen, hal ini merupakan beban psikologis yang harus ditanggung penderita disamping biaya untuk pengobatan yang besar dan ancaman kejadian kematian secara mendadak. ${ }^{6}$ PJK merupakan masalah kesehatan masyarakat yang penting karena morbiditas dan mortalitasnya yang tinggi, ditinjau dari segi pembiayaan akibat waktu perawatan dan biaya pengobatan PJK serta pemeriksaan penunjangnya tentu tidak sedikit. Keberhasilan pengobatan sangat bergantung kepada kecepatan penanganan penyakit, oleh karena itu upaya pencegahan PJK sangat bermanfaat karena sudah pasti lebih murah dan lebih efektif. ${ }^{7}$

PJK ini terjadi secara tidak langsung, biasanya seseorang akan mengalami proses penyempitan pembuluh koroner dalam kurun waktu yang cukup lama. Faktor risiko penyakit jantung koroner terbagi menjadi dua kelompok besar, yaitu : faktor risiko yang tidak dapat dimodifikasi atau tidak dapat dicegah dan faktor risiko yang dapat 
dimodifikasi atau dapat dicegah. Faktor risiko penyakit jantung koroner yang tidak dapat dicegah meliputi usia, riwayat keluarga, jenis kelamin. Faktor risiko yang dapat dicegah antara lain: hipertensi, merokok, hiperlipidemia, diabetes mellitus, aktivitas fisik pasif, serta obesitas. ${ }^{8}$

\section{Metode Penelitian}

Penelitian ini merupakan penelitian deskriptif, mencakup bidang ilmu penyakit dalam dan ilmu penyakit jantung. Penelitian ini dilakukan di rumah sakit Islam Siti Rahmah Padang pada bulan Mei sampai November 2019.

\section{A. Cara Pengelolaan dan Analisis DATA}

Pengolahan data menggunakan komputer dengan program Microsoft excel dan SPSS. Pengolahan data dilakukan dengan beberapa tahap, yaitu :

1) Pemasukan Data

Memasukkan data ke progaram komputer agar dapat dianalisa.

2) Tabulasi Data

Memasukkan data ke tabel yang telah disediakan untuk memudahkan analisis data.

3) Pengeditan Data

Bertujuan untuk mengoreksi data, meliputi kebenaran dan kelengkapan pencatatan.

4) Penghitungan Data

Merupakan tahap akhir dalam penelitian yang hasilnya dapat ditarik kesimpulan yang bermakna

\section{B. Pengolahan Data}

Pengolahan data kategorik ditampilkan dalam bentuk proporsi dan presentasi, seperti jenis kelamin, sedangkan data numerik ditampilkan dalam bentuk data - atau rerata, dan standar deviasi seperti usia.

\section{Hasil Penelitian}

Penelitian dilakukan di RSI Siti Rahmah Padang. Jenis penelitian ini adalah deskriptif. Pendekatan yang digunakan adalah cross sectional dengan melihat data rekam medis pasien PJK periode 2017-2018. Jumlah populasinya yaitu 115 orang dan sampel pada penelitian ini sebanyak 51 orang dengan menggunakan teknik Total Sampling. Berdasarkan hasil pengumpulan dan analisa terhadap data yang telah didapat, maka dapat disimpulkan hasil penelitian dalam paparan di bawah ini:

\section{A. USIA}

Hasil penelitian didapatkan distribusi frekuensi faktor risiko kejadian PJK yang tidak dapat dimodifikasi (usia) di poliklinik jantung Rumah Sakit Islam Siti Rahmah Padang tahun 2017-2018 dapat diuraikan sebagai berikut :

TABel 1. Distribusi Frekuensi USIA PADA Penderita PJK di Poliklinik Jantung RuMah SAKIT ISLAM Siti RAHMAH PAdANG TAHUN 2017 2018

\begin{tabular}{lcc}
\hline Usia & $\boldsymbol{F}$ & $\boldsymbol{\%}$ \\
\hline$<40$ Tahun & 3 & 5.9 \\
40-49 Tahun & 5 & 9.8 \\
50-59 Tahun & 21 & 41.2 \\
60-69 Tahun & 15 & 29.4 \\
>70 Tahun & 7 & 13.7 \\
Jumlah & $\mathbf{5 1}$ & $\mathbf{1 0 0}$ \\
\hline
\end{tabular}

Berdasarkan tabel 1 dapat disimpulkan bahwa dari 51 sampel penderita PJK, usia terbanyak berada pada usia 50-59 tahun yaitu 21 orang $(41,2 \%)$.

\section{B. JeNIS KeLAMIN}

Hasil penelitian didapatkan distribusi frekuensi faktor risiko kejadian PJK yang tidak dapat dimodifikasi (jenis kelamin) di poliklinik jantung Rumah Sakit Islam Siti Rahmah Padang tahun 2017-2018 dapat diuraikan sebagai berikut : 
Tabel 2. Distribusi FrekUensi Jenis Kelamin Pada Penderita PJK di Poliklinik Jantung RUMaH Sakit ISLAM Siti RahMaH Padang TahUN 2017-2018

\begin{tabular}{lcc}
\hline Jenis Kelamin & $\boldsymbol{F}$ & \% \\
\hline Laki-Laki & 25 & 49.0 \\
Perempuan & 26 & 51.0 \\
Jumlah & $\mathbf{5 1}$ & $\mathbf{1 0 0}$ \\
\hline
\end{tabular}

Berdasarkan tabel 2 dapat disimpulkan bahwa dari 51 sampel penderita PJK, jenis kelamin terbanyak adalah perempuan yaitu 26 orang $(51 \%)$.

\section{Hipertensi}

Hasil penelitian didapatkan distribusi frekuensi faktor risiko kejadian PJK yang dapat dimodifikasi (hipertensi) di poliklinik jantung Rumah Sakit Islam Siti Rahmah Padang tahun 2017-2018 dapat diuraikan sebagai berikut :

Tabel 3. Distribusi Frekuensi KeJadian hipertensi Pada Penderita PJK di Poliklinik Jantung Rumah Sakit Islam Siti Rahmah PADANG TAHUN 2017-2018

\begin{tabular}{lcc}
\hline Hipertensi & $\boldsymbol{F}$ & $\boldsymbol{\%}$ \\
\hline Ya & 27 & 52.9 \\
Tidak & 24 & 47.1 \\
Jumlah & $\mathbf{5 1}$ & $\mathbf{1 0 0}$ \\
\hline
\end{tabular}

Berdasarkan tabel 3 dapat disimpulkan bahwa dari 51 sampel penderita PJK, mengalami hipertensi yaitu 27 orang $(52,9 \%)$.

\section{Obesitas}

Hasil penelitian didapatkan distribusi frekuensi faktor risiko kejadian PJK yang dapat dimodifikasi (obesitas) di poliklinik jantung Rumah Sakit Islam Siti Rahmah Padang tahun 2017-2018 dapat diuraikan sebagai berikut :

Tabel 4. Distribusi Frekuensi Obesitas pada Penderita PJK di Poliklinik Jantung Rumah Sakit Islam Siti Rahmah Padang Tahun 20172018

\begin{tabular}{lcc}
\hline Obesitas & $\boldsymbol{F}$ & $\mathbf{\%}$ \\
\hline Ya & 16 & 31.4 \\
Tidak & 35 & 68.6 \\
Jumlah & $\mathbf{5 1}$ & $\mathbf{1 0 0}$ \\
\hline
\end{tabular}

Berdasarkan tabel 4 dapat disimpulkan bahwa dari 51 sampel penderita PJK, tidak mengalami obesitas yaitu 35 orang $(68,6 \%)$.

\section{E. DM}

Hasil penelitian didapatkan distribusi frekuensi faktor risiko kejadian PJK yang dapat dimodifikasi (DM) di poliklinik jantung Rumah Sakit Islam Siti Rahmah Padang tahun 2017-2018 dapat diuraikan sebagai berikut :

Tabel 5. Distribusi Frekuensi DM Pada Penderita PJK di Poliklinik Jantung Rumah Sakit Islam Siti Rahmah Padang Tahun 20172018

\begin{tabular}{lcc}
\hline DM & $\boldsymbol{F}$ & $\boldsymbol{\%}$ \\
\hline Ya & 26 & 51.0 \\
Tidak & 25 & 49.0 \\
Jumlah & $\mathbf{5 1}$ & $\mathbf{1 0 0}$ \\
\hline
\end{tabular}

Berdasarkan tabel 5 dapat disimpulkan bahwa dari 51 sampel penderita PJK, mengalami DM yaitu 26 orang (51\%).

\section{F. Hiperlipidemia}

Hasil penelitian didapatkan distribusi frekuensi faktor risiko kejadian PJK yang dapat dimodifikasi (hiperlipidemia) di poliklinik jantung Rumah Sakit Islam Siti Rahmah Padang tahun 2017-2018 dapat diuraikan sebagai berikut :

TABel 6. Distribusi FrekUenSi HiPerLIPIDEMIA pada Penderita PJK di Poliklinik Jantung RUMaH Sakit ISLAM SITI RaHMAH Padang TAHUN 2017-2018

\begin{tabular}{lcc}
\hline Hiperlipidemia & $\boldsymbol{F}$ & $\mathbf{\%}$ \\
\hline Ya & 13 & 25.5 \\
Tidak & 38 & 74.5 \\
Jumlah & $\mathbf{5 1}$ & $\mathbf{1 0 0}$ \\
\hline
\end{tabular}

Berdasarkan tabel 6 dapat disimpulkan bahwa dari 51 sampel penderita PJK, tidak mengalami hiperlipidemia yaitu 38 orang $(74,5 \%)$. 


\section{Pembahasan}

\section{A. USIA}

Berdasarkan hasil penelitian di RSI Siti Rahmah Padang dari 51 sampel penderita PJK, usia terbanyak berada pada usia 50-59 tahun yaitu 21 orang $(41,2 \%)$. Penelitian ini sesuai dengan penelitian sebelumnya yang dilakukan oleh Zahrawardani (2014) di RSUP DR Kariadi Semarang diperoleh hasil sebanyak $83,6 \%$ pasien dengan usia $>45$ tahun dan penelitian yang dilakukan oleh Muthmainnah (2019) di Poliklinik Jantung dan Pembuluh Darah Rumah Sakit Umum Daerah Ir. Soekarno Kabupaten Sukoharjo diperoleh hasil sebanyak $44,9 \%$ pasien dengan usia 45-59 tahun., ${ }^{9,10}$

Hasil penelitian ini juga sesuai dengan teori pendukung Woodward, et al (2017) bahwa pada usia lansia akhir yaitu $>50$ tahun adalah pasien yang paling banyak mengalami PJK. Semakin tua seseorang maka semakin besar risiko terkena PJK dikarenakan ketahanan dinding vaskuler atau pembuluh darah semakin melemah sehingga mempermudah plak yang sudah ada bertambah parah. Proses degeneratif dan meningkatnya paparan agen berbahaya seperti kolesterol serta proses terjadinya aterosklerosis juga berperan penting seiring dengan bertambahnya usia. Hal ini sekaligus membuktikan pernyataan Tierney (2018), bahwa prevalensi PJK terus meningkat seiring dengan bertambahnya usia seseorang. ${ }^{11,12}$

\section{B. Jenis Kelamin}

Berdasarkan hasil penelitian di RSI Siti Rahmah Padang dari 51 sampel penderita PJK, jenis kelamin terbanyak adalah perempuan yaitu 26 orang (51\%). Hasil penelitian ini didukung penelitian sebelumnya yang dilakukan oleh oleh Farahdika (2015) studi kasus di RS Umum Daerah kota Semarang diperoleh hasil paling banyak pasien PJK adalah perempuan yaitu 23 orang (59\%) dan penelitian Donald
Nababan (2008) di RSU Dr. Pringadi Medan, dari 70 orang ada $47(67,1 \%)$ perempuan. ${ }^{13,14}$

Penelitian ini tidak sejalan dengan penelitian yang dilakukan Niluh (2016) yang dilakukan di RSUP Prof. DR.R.D. Kandou Manado menunjukkan bahwa frekuensi laki-laki lebih besar dibanding dengan perempuan yaitu $77,5 \%$.

Secara jenis kelamin, PJK dua kali lebih beresiko pada laki-laki dibandingkan perempuan. Hal ini dikarenakan laki-laki dipengaruhi oleh gaya hidup yang buruk seperti merokok dan wanita usia produktif memiliki hormon estrogen yang bersifat protektif terhadap kejadian kardiovaskular serta berperan dalam menjaga tingkat HDL tetap tinggi dan LDL rendah, setelah wanita mengalami menopause insiden PJK pada perempuan meningkat dengan cepat dan sebanding dengan insiden PJK pada lakilaki. ${ }^{15,16}$

Berdasarkan hasil penelitian ini diperoleh angka kejadian PJK hampir sama laki-laki dan perempuan. Hal ini terjadi karena pada usia 50 tahun keatas wanita dan pria memiliki tingkat risiko PJK yang sama.

\section{Hipertensi}

Berdasarkan hasil penelitian di RSI Siti Rahmah Padang dari 51 sampel penderita PJK, mengalami hipertensi yaitu 27 orang $(52,9 \%)$. Penelitian ini sejalan dengan penelitian sebelumnya yang dilakukan oleh Farahdika (2015) studi kasus di RS Umum Daerah kota Semarang diperoleh hasil 68,2\% pasien PJK mengalami hipertensi dan penelitian Muthmainnah (2019) juga diperoleh hasil sebanyak 55,1\% pasien PJK mengalami hipertensi. ${ }^{10,13}$

Hasil penelitian ini sesuai dengan teori yang mengatakan bahwa hipertensi adalah salah satu faktor penyebab terjadinya PJK. Ketika berkontraksi untuk membuka paksa katup semilunar, ventrikel harus menghasilkan

Email : heme@unbrah.ac.id 
cukup tekanan untuk melebihi tekanan darah di arteri-arteri besar. Tekanan darah arteri disebut beban akhir karena merupakan beban kerja yang ditimpakan ke jantung setelah kontraksi dimulai. Jika tekanan arteri terusmenerus tinggi (hipertensi) atau jika katup menyempit, ventrikel harus menghasilkan tekanan lebih besar untuk memompa darah ke seluruh tubuh. Hal ini akan menyebabkan penebalan otot jantung dan hilangnya elastisitas dari otot itu.

Berbeda dengan otot lengan atau otot perut yang terlatih akan menjadi lebih kuat, otot jantung yang menebal pada akhirnya akan mengalami penurunan fungsi terutama fungsi pompa jantung yang menurun. Penurunan fungsi ini akan menyebabkan angina. Hal inilah yang mendasari PJK lebih sering didapatkan pada penderita hipertensi dibanding orang yang tidak mengalami hipertensi. ${ }^{17}$

\section{Obesitas}

Berdasarkan hasil penelitian di RSI Siti Rahmah Padang dari 51 sampel penderita PJK, mengalami obesitas yaitu 16 orang $(31,4 \%)$. Hasil penelitian ini sejalan dengan penelitian sebelumnya yang dilakukan oleh Muthmainnah (2019) diperoleh hasil sebanyak 27 orang $(22,9 \%)$ mengalami obesitas atau kegemukan tetapi berbeda dengan penelitian Farahdika (2015) diperoleh hasil sebanyak 63\% pasien PJK mengalami obesitas. $^{18,13}$

Obesitas secara tidak langsung meningkatkan risiko terkena aterosklerosis dan penyakit kardiovaskular lainnya. Orang yang obesitas memiliki beberapa peningkatan risiko, antara lain terkena hipertensi, cenderung memiliki kadar lipid tinggi (hiperlipidemia) dan berisiko berkembang menjadi DM. Hasil penelitian ini menunjukan angka yang rendah pada kejadian obesitas dikarenakan secara teori tidak ada pengaruh yang signifikan antara orang yang obesitas dengan tidak obesitas, karena keduanya memiliki faktor risiko yang sama besarnya. Meskipun frekuensinya rendah, obesitas tidak boleh disepelekan. Orang yang mengalami obesitas dengan faktor risiko lain penyakit kardiovaskular seperti hipertensi, DM, dan hiperlipidemia sebaiknya membuat perubahan gaya hidup untuk menurunkan berat badan agar mengurangi faktor risiko terjadinya aterosklerosis. ${ }^{19}$

\section{E. DM}

Berdasarkan hasil penelitian di RSI Siti Rahmah Padang dari 51 sampel penderita PJK, mengalami DM yaitu 26 orang (51\%). Hasil penelitian ini sejalan dengan penelitian Zahrawardani (2014) di RSUP Dr Kariadi Semarang diperoleh hasil pasien menderita diabetes melitus $64,10 \%$ dan penelitian yang dilakukan oleh Marleni dan Alhabib (2017) diperoleh hasil sebanyak 123 orang $(96,9 \%)$ penderita PJK mengalami diabetes mellitus. Penelitian ini tidak sejalan dengan penelitian yang dialkukan oleh Muthmainnah (2019) diperoleh hasil hanya sebanyak 13,6\% pasien mengalami DM. ${ }^{9,10,20}$

Hasil penelitian ini sesuai dengan teori yang mengatakan bahwa pasien DM berisiko lebih besar terjadinya PJK dari pada individu yang tidak DM. DM dapat meyebabkan disfungsi endotel dan selanjutnya menimbulkan aterosklerosis. Beberapa penyebab DM yang dapat menimbulkan disfungsi endotel antara lain yaitu hiperglikemia, peningkatan FFA, dan resistensi insulin.

Hiperglikemia akan merusak ekstrasel dan intrasel jaringan kardiovaskuler yang tidak mampu membatasi pemasukan glukosa ke dalam sel. Hiperglikemia juga dapat meningkatkan autooksidasi dan radikal bebas melalui proses stres oksidatif yang dapat menyebabkan disfungsi endotel sebagai awal proses aterosklerosis selanjutnya. Peningkatan FFA pada penderita DM disebabkan proses lipolisis yang berlebihan dari jaringan adiposa dan penurunan uptake oleh sel jaringan terutama 
otot skeletal. FFA dapat mengganggu fungsi endotel melalui beberapa mekanisme yaitu peningkatan produksi radikal bebas, aktivasi protein kinase $\mathrm{C}$, dan eksaserbasi dislipidemia. Resistensi insulin yang menyertai DM meningkatkan terjadinya disfungsi endotel. Hubungan antara hiperinsulinemia, resistensi insulin sampai disfungsi endotel merupakan hubungan yang berkelanjutan dalam terjadinya aterosklerosis. ${ }^{25}$

\section{F. HiperLipideMIA}

Berdasarkan hasil penelitian di RSI Siti Rahmah Padang dari 51 sampel penderita PJK, mengalami hiperlipidemia yaitu 13 orang $(25,5 \%)$. Hasil penelitian ini berbeda dengan penelitian Damayanti (2017) di RS Islam Surabaya diperoleh hasil $50,8 \%$ pasien mengalami hiperlipidemia dan penelitian Marufi dan Rosita (2014) diperoleh hasil paling banyak pasien dengan hyperlipidemia yaitu $53,2 \% .^{26,27}$

Hiperlipidemia merupakan peningkatan kolesterol, fosfolipid, trigliserida, dan asam lemak. Dalam ikatan bersama protein, lemak membentuk kilomikron, lipoprotein densitas sangat rendah, rendah dan tinggi (VLDL, LDL, HDL). Profil lipid ditetapkan dengan mengukur kolesterol total, kolesterol HDL, kolesterol LDL, dan trigliserida. Konsekuensi hiperlipidemia yang paling penting adalah peningkatan kolesterol serum, terutama peningkatan LDL yang merupakan predisposisi terjadinya aterosklerosis serta meningkatnya risiko terjadinya PJK, sedangkan HDL bersifat protektif terhadap kemungkinan pengendapan aterosklerosis. ${ }^{28}$

Kolesterol LDL (Low Density Lipoprotein) adalah kolesterol yang terkandung dalam lipoprotein berdensitas rendah dengan kombinasi sedikit trigliserida, fosfolipid sedang dan kolesterol tinggi. LDL berperan dalam proses penimbunan kolesterol dalam makrofag, sel otot polos serta matriks ekstra seluler dalam pembuluh darah sehingga bersifat aterogenik. Bila LDL diatas normal maka akan membawa kolesterol ke jaringan tubuh dan menyebabkan aterosklerosis. Diantara seluruh jenis lipoprotein yang ada, LDL memiliki porsi pengikatan kolesterol terbanyak, yakni sekitar 70-75\%, karena itu kolesterol LDL lebih tepat sebagai petunjuk untuk mengetahui risiko PJK daripada kadar kolesterol total. Penelitian ini memiliki hasil yang berbeda dengan penelitian lainnya karena jumlah sampel penelitian yang terbatas. $^{29}$

\section{Penutup}

\section{A. Kesimpulan}

Berdasarkan gambaran faktor risiko kejadian penyakit jantung koroner di poliklinik jantung RSI Siti Rahmah Padang tahun 2017-2018, maka dapat disimpulkan bahwa :

Frekuensi usia terbanyak berada pada usia 5059 tahun yaitu 21 orang $(41,2 \%)$. Frekuensi jenis kelamin terbanyak adalah perempuan yaitu 26 orang $(51 \%)$. Frekuensi hipertensi pada PJK yaitu 27 orang (52,9\%). Frekuensi obesitas pada PJK yaitu 16 orang $(31,4 \%)$. Frekuensi DM pada PJK yaitu 26 orang (51\%). Frekuensi hiperlipidemia yaitu 13 orang $(25,5 \%)$.

\section{B. SARAN}

Bagi masyarakat terutama pada usia menuju lansia agar selalu menerapkan pola hidup sehat dan memperhatikan kesehatan jantung seperti ikut serta dalam program senam jantung sehat yang diadakan oleh Puskesmas sekitar. Laki-laki dan perempuan agar menerapkan pola hidup sehat seperti menghindari konsumsi asupan makanan dan minuman yang bisa memicu terjadinya PJK serta menghindari faktor risiko yang dapat memicunya. Pasien PJK agar menghindari hal yang memicu terjadinya hipertensi seperti tidak mengkonsumsi makanan yang mengandung kolesterol tinggi dan menghindari stress berlebihan.

Email : heme@unbrah.ac.id 
1. Disarankan bagi pasien PJK agar menurunkan berat badan sesuai dengan berat badan ideal dan selalu mengontrol asupan makanan agar berat badan tidak semakin meningkat bagi pasien yang mengalami obesitas.

2. Selalu mengontrol gula daeah dan melakukan pengecekan gula darah di Puskesmas terdekat dan juga mengatur pola makan sesuai takaran bagi pasien yang mengalami DM.

3. Selalu mengontrol kadar lipid agar selalu pada kondisi normal dan stabil dengan menerapkan pola hidup sehat.

\section{Daftar Pustaka}

[1] Kementerian Kesehatan. 2013. Laporan Riset Kesehatan Dasar (Riskesdas) Bidang Biomedis. Jakarta: Badan Litbangkes, Kemenkes RI; 2014.

[2] WHO. 2014. Cardiovascular Disease Risk Factors. Pdf [cited 2015-1809].http://www.ahlinyapenyakitjantung.web.id/an gka-kematian-penyakit-jantung-diindonesia/.dpuf.

[3] Kementerian Kesehatan. 2018. Laporan Riset Kesehatan Dasar (Riskesdas) Bidang Biomedis. Jakarta: Badan Litbangkes, Kemenkes RI; 2019.

[4] Delima, Mihardja L, Siswoyo H. 2009. Prevalensi dan faktor determinan penyakit jantung di Indonesia. Buletin Penelit. Kesehatan. 37 (3) : 142-159.

[5] Dinas Kesehatan Provinsi Sumatera Barat. 2016. Profil Kesehatan Propinsi Sumatera Barat. Padang.

[6] Sanchis-Gomar, Perez-Quilis, Leischik and Lucia. 2016. Epidemiology of Coronary Heart Disease and Acute Coronary Syndrome. Annals of Translational Medicine. Jul; 4(13): 256. Doi.10.21037/atm.2016.06.33.

[7] Nabel, E. G. and Braunwald, E. 2012. A Tale of Coronary Artery Disease and Myocardial Inferction. The New England Journal of Medicine. 366: 54-63.

[8] Hamrefors, Hedblad, Hindy, Smith, Alingren, Engstrom, Sjogren, et.al. 2014. Smoking Modifies The Associated Increased Risk of Future Cardiovaskular Disease by Genetic Variation on Cromosome 9p21. Plos One. Vol 9 (1): e85893.

[9] 27. Zahrawardani, Diana. 2014. Analisis Faktor Risiko Kejadian Penyakit Jantung Koroner di RSUP Dr Kariadi Semarang (skripsi). Semarang: Fakultas Kedokteran Universitas Muhammadiyah Semarang.

[10] 28. Muthmainnah, Qowiyatul. 2019. Gambaran Faktor Risiko Kejadian Penyakit Jantung Koroner (skripsi). Surakarta: Fakultas Ilmu Kesehatan Universitas Muhammadiyah Surakarta.

[11] Woodward M, Barzi F, Feigin V, Gu D, Huxley R, Nakamura K. 2007. Associations between highdensity lipoprotein cholesterol and both stroke and coronary heart disease in the Asia Pacific region. Eur.Heart.J. 28, 2653-60.

[12] Tierney LM. 2018. Coronary Heart Disease , In : McPhee SJ, Papadakis MA (eds), Current Medical Diagnosis \& Treatment. McGraw Hill Professional. 300.

[13]Farahdika, Amelia. 2015. Faktor Risiko Yang Berhubungan Dengan Penyakit Jantung Koroner Pada Usia Dewasa Madya (41-60 Tahun) (Studi Kasus Di RSU Daerah Kota Semarang) (skripsi). Semarang: Universitas Negeri Semarang.

[14] Nababan, D. 2008. Hubungan Faktor Resiko dan Karakterisitik Penderita Dengan Kejadian Penyakit Jantung Koroner di RSU DR. PirngadiMedan. Diakses tanggal 01 Pebruari 2017. Medan: UISU

[15] Niluh, E.C. 2016. Gambaran Penyakit Jantung Koroner Pada Pasien Gagal Jantung yang Menjalani Rawat Inap di RSUP Prof. Dr. R. D. Kandou Periode September-November, Jurnal eClinic (eCL), Universitas Sam Ratu Langi Manado; Vol.4 (2). 14. Pramadiaz, A.T., Fadil.

[16] Eaker, E.D. 2016. Psychological factors in the epidemiology of coronary heart disease in women, Psychiatric Clinic of North America vol 12, hal 167174.

[17] Octavius Herman, Agung Albertus, Ramadhani Dian. 3013. Introduction to human physiology 8 Ed. In: Sherwood, Lauralee. EGC. p352-356.

[18] Majid, A. 2013, Mei 25. Penyakit Jantung Koroner: Patofisiologi, Pencegahan, dan Prognosis. Retrieved from http:// respository.usu.ac.id/bitstream/123456789/705/1/ 08E00124.pdf

[19] Indriyanti RS. 2014. Obesitas dan Sindroma Kardiovaskular Dismetabolik, Informasi Laboratorium. Laboratorium Klinik Prodia. Jakarta.

[20] Marleni, L., \& Alhabib, A. 2017. Faktor-Faktor Penyakit Jantung Koroner di RSI SITI Khadijah Palembang: Jurnal Kesehatan, 3(3), 478-483.

[21] Budiono, Bambang. 2006. Sindroma metabolik dan Penyakit kardiovaskuler. Fakultas Kedokteran Universitas Hasanuddin. Makassar .

[22] Damayanti, Fidya Panorama. 2017. Analisis Survival Penyakit Jantung Koroner Berulang (skripsi). Surabaya: Fakultas Kesehatan Masyarakat Universitas Airlangga.

[23] Ma'rufi, Rosita, L. 2014. Hubungan Dislipidemia Dan Kejadian Penyakit Jantung Koroner (skripsi). Yogyakarta: Fakultas Kedokteran Universitas Islam Indonesia.

[24] Mokogenta, Rahpan. 2015. Parameter Lipid dan 
Heme, Vol III No 1

January 2021

Lipoprotein Sebagai Faktor Risiko Penyakit Jantung Koroner di RS Wahidin Sudirohusodo. Surakarta.

[25] Saputri, V.F., \& Herawati, T.M. 2016. FaktorFaktor Risiko Yang Berhubungan Dengan Kejadian Penyakit Jantung Koroner (PJK) Pada Usia Dewasa Di RS Haji Jakarta: Jurnal Ilmiah Kesehatan, 8(2), 74-79.

[26] Iryani, D., Oenzil F., \& Yuliani F. 2014. Hubungan Berbagai Fakor Risiko Terhadap Kejadian Penyakit Jantung Koroner Pada Penderita Diabetes Melitus Tipe 2: Jurnal Kesehatan Andalas, 3(1), 1-4.

[27] Diastutik, D. 2016. Proporsi Karakteristik Penyakit Jantung Koroner Pada Perokok Aktif Berdasarkan Karakteristik Merokok: Jurnal Berkala Epidemiologi, 4(3), 326-337.

[28] 24.Nurrohmah, A., \& Salim, A.Y. 2013. Hubungan Olahraga Dengan Kejadian Penyakit Jantung Koroner Di RSUD Dr. Moewardi: GASTER, 10(1), 48-56

[29] Mirjana D, Edita S, Biljana V, Suncica KD, Velibor C. 2016 Lipids and Atherosclerosis. Jugoslov Med Biohem. 25(4):325- 333.

Email : heme@unbrah.ac.id 